\title{
Free radical scavenging activity and phenolic contents of Anthocleista djalonensis (Loganiaceae) leaf extract
}

\author{
Francis M. AWAH ${ }^{1,2 *}$, Emmanuel TUFON ${ }^{1}$ and Peter N. UZOEGWU ${ }^{1}$ \\ ${ }^{1}$ Department of Biochemistry, Tropical Disease Research Unit, University of Nigeria, Nsukka, \\ Enugu State, Nigeria. \\ ${ }^{2}$ Department of Biochemistry, Natural Products Research Unit, Madonna University, Elele Campus, \\ River State, Nigeria. \\ *Corresponding author; E-mail: awambuh@yahoo.com; Tel: (234)-805-743-1113.
}

\begin{abstract}
Anthocleista djalonensis extract is widely used in Nigerian folk medicine to treat conditions whose pathogenesis implicate oxidative stress, such as diabetes and hepatitis. However, little is known of the mechanism underlying these activities. In this study, the free radical scavenging potential of a methanol extract of $A$. djalonensis leaves was assessed by measuring its capability for scavenging 2,2-diphenyl-1-picrylhydrazyl (DPPH) radical, superoxide anion radical $\left(\mathrm{O}_{2}{ }^{-}\right)$, hydroxyl radical $\left({ }^{\circ} \mathrm{OH}\right)$, nitric oxide radicals (NO), as well as its ability to inhibit lipid peroxidation, using appropriate assay systems compared to natural and synthetic antioxidants. Total phenolic, flavonoid and flavonol contents were determined by spectrophotometric methods. This extract showed a very potent $\mathrm{DPPH}$ and $\mathrm{O}_{2}{ }^{-}$anion radical scavenging activities $\left(\mathrm{IC}_{50}=8.69 \pm 0.95 \mu \mathrm{g} / \mathrm{ml}\right.$ and $5.32 \pm 1.05 \mu \mathrm{g} / \mathrm{ml}$ respectively) and also significantly inhibited the accumulation of nitrite in vitro. The $\mathrm{OH}$ radical and non-enzymatic lipid peroxidation inhibitory potentials of the extract were significantly higher ( $\mathrm{p}<0.05$ ) than that of standard antioxidants $\left(\mathrm{IC}_{50}=33.06 \pm 5.65 \mu \mathrm{g} / \mathrm{ml}\right.$ and $59.14 \pm 4.64 \mu \mathrm{g} / \mathrm{ml}$ respectively). The plant extract yielded $0.989 \pm 0.097 \mathrm{mg}$ gallic acid equivalents phenolic content and $48.52 \pm 1.10 \mathrm{mg}$ rutin equivalents flavonoid content. The present study provides evidence that the methanol extract of $A$. djalonensis is a potential source of natural antioxidants. The observed antioxidant potentials of the extract suggest that it could impart health benefits when consumed. However, further investigation to verify its effect in vivo and isolate the active principles is warranted.
\end{abstract}

(c) 2010 International Formulae Group. All rights reserved.

Keywords: Anthocleista djalonensis, free radical scavenging activity, phenolic contents.

\section{INTRODUCTION}

Free radicals are highly reactive unstable molecules that have an unpaired electron in their outer shell; superoxide $\left(\mathrm{O}_{2}{ }^{-}\right)$, hydroxyl $(\cdot \mathrm{OH})$, peroxyl (ROO), peroxinitrite ( $(\mathrm{NOO})$, and nitric oxide (NO) radicals, formed during a variety of biochemical reactions (Atta-ur-Rahman and Choudhary, 2001). They react with various cellular components including DNA, proteins, and lipids leading to mitochondrial malfunction, cell membrane damage and eventually apoptosis. Free radicals have been implicated in the etiology of a wide variety of diseases such as neurodegenerative diseases, heart disease, HIV/AIDS, cardiovascular disease, diabetes, hepatitis and cancer (Halliwell, 2001; Eze, 2006). Recently, the use of 
antioxidants from natural sources has become more popular as a means of increasing the shelf-life of food products, slowing down the ageing process and in the treatment of human diseases (Wong et al., 2006; Mosquera et al., 2007). Since radicals are involved in all of these clinical conditions, antioxidants could effectively prevent their occurrence.

The plant species Anthocleista djalonensis (Loganiaceae) grows in wild form in tropical and subtropical regions of America, and in Africa it is widely used in Nigerian folk medicine to treat sexually transmitted infections (STI) and has been reported to have several functions including anti-diabetes, antimalarial, anti-pyretic, anthelmintic, antimycobacterial, anti-bacterial and wound healing properties (Okoli and Iroegbu, 2004; Chah et al., 2006; Nweze and Ngongeh, 2007; Esimone et al., 2009). However, its antioxidant potential has not been investigated. Since oxidative stress is reported to be a hallmark in the pathogenesis of the above disease conditions, we have therefore, investigated in this study the free radical scavenging capacity of a methanol extract of A. djalonensis (MEAD) in different assay systems, and determine its phenolic contents. This is aimed at providing a possible explanation for the ethnopharmacological claims attributed to the plant.

\section{MATERIALS AND METHODS}

\section{Chemicals}

L-ascorbic acid, and 2,2-diphenyl-1picrylhydrazyl (DPPH) radical were purchased from Fluka Chemicals, 2-deoxy-Dribose, sodium nitroprusside (SNP), sodium nitrite, sulpanilamide, phosphate buffer saline (PBS), phosphoric acid, potassium dihydrogen phosphate $\left(\mathrm{KH}_{2} \mathrm{PO}_{4}\right)$, potassium hydroxide (KOH), ferric chloride $\left(\mathrm{FeCl}^{3+}\right)$, naphthylethylenediamine dihydrochloride, ethylenediaminetetraacetic acid (EDTA), nitro blue tetrazolium (NBT), sodium carbonate $\left(\mathrm{Na}_{2} \mathrm{CO}_{3}\right)$, aluminium trichloride, perchloric acid $\left(\mathrm{HClO}_{4}\right)$, butylated hydroxyltoluene (BHT), polyvinylpolypyrrolidone, riboflavin, ferrous sulphate, hydrogen peroxide $\left(\mathrm{H}_{2} \mathrm{O}_{2}\right)$, thiobarbituric acid (TBA), Folin-ciocalteu reagent (FCR) and trichloroacetic acid (TCA) were all purchased from Sigma Chemical Co. (St. Louis, MO).

\section{Crude plant extract preparation}

The leaves of $A$. djalonensis were collected in June 2009 from Nneni, South Eastern Nigeria. The plant was identified at the Herbarium, University of Nigeria, Nsukka, air-dried at room temperature and reduced to fine powder by milling. The resulting powder was subjected to extraction with $80 \%$ methanol, concentrated using a rotary evaporator and stored at $4{ }^{\circ} \mathrm{C}$ until used.

\section{Antioxidant activity assays \\ Quantitative DPPH radical-scavenging assay}

Scavenging activity on DPPH free radicals by the extract was assessed according to the method reported by Gyamfi et al. (1999) with slight modifications (Awah et al., 2010). Briefly, a $2.0 \mathrm{ml}$ solution of the extract at different concentrations diluted two-fold in methanol was mixed with $1.0 \mathrm{ml}$ of $0.3 \mathrm{mM}$ DPPH in methanol. The mixture was shaken vigorously and allowed to stand at room temperature in the dark for 25 min. Blank solutions were prepared with each test sample solution $(2.0 \mathrm{ml})$ and $1.0 \mathrm{ml}$ of methanol while the negative control was $1.0 \mathrm{ml}$ of 0.3 $\mathrm{mM}$ DPPH solution plus $2.0 \mathrm{ml}$ of methanol. L-ascorbic acid was used as the positive control. Thereafter, the absorbance of the assay mixture was measured at $518 \mathrm{~nm}$ against each blank with a UV-visible spectrophotometer. DPPH radical inhibition was calculated using the equation:

$\% \quad$ Inhibition $=\left(\frac{A_{0}-A_{s}}{A_{0}}\right) \times 100$

where $A_{0}$ is the absorbance of the control, and $A_{\mathrm{s}}$ is the absorbance of the tested sample. The $\mathrm{IC}_{50}$ represented the concentration of the extract that inhibited $50 \%$ of radical.

Hydroxyl radical ( $\mathrm{OH}$ )-scavenging assay

The 2-deoxyribose assay was used to determine the scavenging effect of the extract on the $\mathrm{OH}$ radical, as reported by Halliwell et 
al. (1987) with minor modifications (Awah et al., 2010). Each reaction mixture contained, the following final concentrations of reagents in a final volume of $1.0 \mathrm{ml}$ : 2-deoxyribose (2.5 $\mu \mathrm{M})$, potassium phosphate buffer $(\mathrm{pH}$ 7.4, $20 \mathrm{mM}), \mathrm{FeCl}_{3}(100 \mu \mathrm{M})$, EDTA (104 $\mu \mathrm{M}), \mathrm{H}_{2} \mathrm{O}_{2}(1 \mathrm{mM})$, and L-ascorbic acid (100 $\mu \mathrm{M})$. The mixtures were incubated for $1 \mathrm{~h}$ at $37{ }^{\circ} \mathrm{C}$, followed by addition of $1.0 \mathrm{ml}$ of $1 \%$ (w/v) TBA in $0.05 \mathrm{M} \mathrm{NaOH}$ and $1.0 \mathrm{ml}$ of $2.8 \%(w / v)$ TCA. The resulting mixture was heated for $15 \mathrm{~min}$ at $100{ }^{\circ} \mathrm{C}$. After cooling on ice, absorbance was measured at $532 \mathrm{~nm}$. Inhibition of 2-deoxyribose degradation expressed in percentage was calculated as per the equation:

$\% \quad$ Inhibition $=\left(\frac{A_{0}-A_{s}}{A_{0}}\right) \times 100$

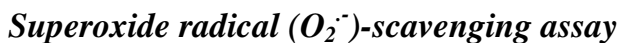

This assay was based on the capacity of the extract to inhibit the photochemical reduction of nitro blue tetrazolium (NBT) as described by Martinez et al. (2001) with slight modifications (Awah et al., 2010). Briefly, each $3.0 \mathrm{ml}$ reaction mixture contained 0.05 M PBS (pH 7.8), 13 mM methionine, $2 \mu \mathrm{M}$ riboflavin, $100 \mu \mathrm{M}$ EDTA, NBT $(75 \mu \mathrm{M})$ and $1.0 \mathrm{ml}$ of test sample solutions. The tubes were kept in front of a fluorescent light (725 lumens, 34 watts) and absorbance was read at $560 \mathrm{~nm}$ after $20 \mathrm{~min}$. The entire reaction assembly was enclosed in a box lined with aluminum foil. The inhibition of superoxide anion was estimated as per the equation:

$\% \quad$ Inhibition $=\left(\frac{A_{0}-A_{s}}{A_{0}}\right) \times 100$

\section{Lipid peroxidation assay}

A modified thiobarbituric acid-reactive species (TBARS) assay (Awah et al., 2010) was used to measure the lipid peroxide formed, using egg yolk homogenates as lipidrich media (Ruberto et al., 2000). Briefly, egg homogenate $(500 \mu \mathrm{l}$ of $10 \%$, v/v in PBS (pH 7.4) and $100 \mu \mathrm{l}$ of samples were added to a test tube and made up to $1.0 \mathrm{ml}$ with distilled water. Then, $50 \mu \mathrm{l}$ of $\mathrm{FeSO}_{4}(0.075 \mathrm{M})$ and 20 $\mu \mathrm{l}$ of L-ascorbic acid $(0.1 \mathrm{M})$ were added and all were mixed and incubated for $1 \mathrm{~h}$ at $37{ }^{\circ} \mathrm{C}$ to induce lipid peroxidation. Thereafter, 0.2 $\mathrm{ml}$ of EDTA $(0.1 \mathrm{M})$ and $1.5 \mathrm{ml}$ of TBA reagent (3 g TBA, $120 \mathrm{~g}$ TCA and $10.4 \mathrm{ml}$ $70 \% \mathrm{HClO}_{4}$ in $800 \mathrm{ml}$ of distilled water) were added in each sample and heated for $15 \mathrm{~min}$ at $100{ }^{\circ} \mathrm{C}$. After cooling, samples were centrifuged for $10 \mathrm{~min}$ at $3000 \mathrm{rpm}$ and absorbance of supernatant was measured at $532 \mathrm{~nm}$. Lipid peroxidation inhibition was calculated as per the equation:

$\% \quad$ Inhibition $=\left(\frac{A_{0}-A_{s}}{A_{0}}\right) \times 100$

\section{Determination of total phenolic contents}

Total phenolics were determined using Folin-ciocalteu reagent (FCR) as described by Velioglu et al. (1998), with slight modifications. Briefly, $100 \mu \mathrm{l}$ of the extract dissolved in methanol $(1 \mathrm{mg} / \mathrm{ml})$ was mixed with $750 \mu \mathrm{l}$ of FCR (diluted 10-fold) and allowed to stand at $22{ }^{\circ} \mathrm{C}$ for $5 \mathrm{~min} ; 750 \mu \mathrm{l}$ of $\mathrm{Na}_{2} \mathrm{CO}_{3}(60 \mathrm{~g} / \mathrm{l})$ solution was then added to the mixture. After $90 \mathrm{~min}$ the absorbance was measured at $725 \mathrm{~nm}$. Results were expressed as gallic acid equivalents.

\section{Determination of tannin contents}

Tannin content in each sample was determined using insoluble polyvinylpolypirrolidone (PVPP), which binds tannins as described by Makkar et al. (1993). Briefly, $1 \mathrm{ml}$ of extract dissolved in methanol (1 $\mathrm{mg} / \mathrm{ml}$ ), in which the total phenolics were determined, was mixed with $100 \mathrm{mg}$ PVPP, vortexed, left for $15 \mathrm{~min}$ at $4{ }^{\circ} \mathrm{C}$ and then centrifuged for $10 \mathrm{~min}$ at $3000 \mathrm{rpm}$. In the clear supernatant the non-tannin phenolics were determined the same way as the total phenolics (Velioglu et al., 1998). Tannin content was calculated as a difference between total and non-tannin phenolic content.

\section{Determination of flavonoids and flavonols}

The flavonoids content was determined according to the method described by Kumaran and Karunakaran (2006) with slight modifications. Briefly, $100 \mu \mathrm{l}$ of plant extracts in methanol $(10 \mathrm{mg} / \mathrm{ml})$ was mixed with 100 $\mu 1$ of $20 \%$ aluminium trichloride in methanol and a drop of acetic acid, and then diluted with methanol to $5 \mathrm{ml}$. The absorbance at 415 
nm was read after 40 min. Blank samples were prepared from $100 \mu \mathrm{l}$ of plant extracts and a drop of acetic acid, and then diluted to 5 $\mathrm{ml}$ with methanol. The absorption of standard rutin solution $(0.5 \mathrm{mg} / \mathrm{ml})$ in methanol was measured under the same conditions. The amount of flavonoids in the plant extract in rutin equivalents (RE) was calculated by the following formula:

Flavonoid content $=\frac{A \times m_{0}}{A_{0} \times m}$

where $A$ is the absorbance of plant extract solution, $A_{o}$ is the absorbance of standard rutin solution, $m$ is the weight of plant extract $(\mathrm{mg})$ and $m_{o}$ is the weight of rutin in the solution (mg).

The content of flavonols was also determined as described by Kumaran and Karunakaran (2006) with slight modifications. Briefly, $1 \mathrm{ml}$ of methanolic extract $(10 \mathrm{mg} / \mathrm{ml})$ was mixed with $1 \mathrm{ml}$ aluminium trichloride $(20 \mathrm{mg} / \mathrm{ml})$ and $3 \mathrm{ml}$ sodium acetate (50 $\mathrm{mg} / \mathrm{ml})$. The absorbance at $440 \mathrm{~nm}$ was read after $2.5 \mathrm{~h}$. The absorbance of standard rutin solution $(0.5 \mathrm{mg} / \mathrm{ml})$ in methanol was also measured under the same conditions. The amount of flavonols in the extract was calculated by the same formula for flavonoids.

\section{Statistical analysis}

The results were analyzed using the Statistical Package for Social Sciences (SPSS) version 10.0 for Windows. All the data are expressed as mean \pm SEM $(n=3)$. Student's ttest was used to compare means, and values were considered significant at $\mathrm{p}<0.05$.

\section{RESULTS}

\section{Effect of MEAD on DPPH radicals}

As shown in Figure 1, the MEAD possessed substantial dose-dependent antioxidant activity with $32 \mu \mathrm{g} / \mathrm{ml}$ of extract almost completely inhibiting DPPH radical (91\%). The standard antioxidant L-ascorbic acid had a significantly lower $(\mathrm{p}<0.05) \quad \mathrm{IC}_{50}$ for DPPH radical scavenging potentials $\left(\mathrm{IC}_{50}\right.$ $=4.35 \pm 0.51 \mu \mathrm{g} / \mathrm{ml}$ ) compared to the extract $\left(\mathrm{IC}_{50}=8.69 \pm 0.95 \mu \mathrm{g} / \mathrm{ml}\right)$.

\section{Effect of MEAD on $\mathrm{Fe}^{3+}$-dependent hydroxyl ( $\cdot \mathrm{OH})$ radicals}

The free radical scavenging capabilities of the extract was further established by investigating its ability to scavenge $\mathrm{OH}$ radical, using a $\mathrm{Fe}^{3+}$-dependent hydroxylradical generation assay. The extract was observed to strongly inhibit hydroxyl radicalinduced deoxyribose degradation in a nonsite-specific assay in a concentration dependent manner (Figure 2). The $\mathrm{IC}_{50}$ values (Table 1) of the extract and standard in this assay were $33.06 \pm 5.65 \mu \mathrm{g} / \mathrm{ml}$ and $232.31 \pm$ $6.97 \mu \mathrm{g} / \mathrm{ml}$, respectively. The $\mathrm{IC}_{50}$ value of the extract was significantly $(\mathrm{p}<0.05)$ less than that of the standard.

\section{Effect of MEAD on superoxide anion $\left(\mathrm{O}_{2}{ }^{-}\right)$ radicals}

The ability of the extract to scavenge $\mathrm{O}_{2}{ }^{--}$radical generated from the photochemical reduction of riboflavin resulted in a decrease in the absorbance of the blue formazan solution at $560 \mathrm{~nm}$. As shown in Figure 3, the activity was concentration dependent. The $\mathrm{IC}_{50}$ values (Table 2) of the plant extract and rutin on $\mathrm{O}_{2}{ }^{-}$scavenging activity were $5.32 \pm$ $1.05 \mu \mathrm{g} / \mathrm{ml}$ and $3.47 \pm 0.65 \mu \mathrm{g} / \mathrm{ml}$, respectively. The $\mathrm{IC}_{50}$ value of the extract was not significantly different $(\mathrm{p}>0.05)$ from that of the standard. At $250 \mu \mathrm{g} / \mathrm{ml}$, the percentage inhibition of the plant extract was $92.8 \%$ whereas that of rutin was $98.3 \%$. The $\mathrm{O}_{2}{ }^{-}$ radical scavenging effect of the extracts could culminate in the prevention of $\mathrm{OH}$ radical formation since $\mathrm{O}_{2}^{--}$and $\mathrm{H}_{2} \mathrm{O}_{2}$ are required for $\mathrm{OH}$ radical generation.

\section{Effect of MEAD on lipid peroxidation}

The TBARS formation assay was used to assess the inhibition of $\mathrm{Fe}^{2+}$-induced lipid peroxidation by the extract. The MEAD showed a very good dose-dependent inhibition of lipid peroxidation compared to the standard antioxidant BHT (Figure 4) with $\mathrm{IC}_{50}$ value of $59.14 \pm 4.64 \mu \mathrm{g} / \mathrm{ml}$ significantly lower $(\mathrm{p}<0.05)$ than that of the standard $216.27 \pm$ $7.92 \mu \mathrm{g} / \mathrm{ml}$ (Table 1). 


\section{Effect of MEAD on NO radical production}

Nitric oxide (NO) released from SNP has a strong $\mathrm{NO}^{+}$character which can alter the structure and function of many cellular components. In this study the MEAD in SNP solution significantly inhibited $(p<0.05)$ the accumulation of nitrite, a stable oxidation product of NO liberated from SNP in the reaction medium with time compared to the standard $\alpha$-tocopherol (Figure 5). The MEAD exhibited a strong concentration dependent NO radical scavenging activity with 250 $\mu \mathrm{g} / \mathrm{ml}$ of extract scavenging most efficiently.
Total phenolics, tannins, flavonoids and flavonols contents

As shown in Table 2, phenolic compounds were a major class of bioactive components in the extract. Phenolic compounds may contribute directly to antioxidative action. The total phenolic content was $0.989 \pm 0.097 \mathrm{mg}$ gallic acid equivalents/mg dry weight plant extract. The total flavonoid content and the flavonol subclass of the $80 \%$ methanol extract of $\mathrm{A}$. djalonensis were $48.52 \pm 1.10$ and $28.52 \pm$ $0.34 \mathrm{mg}$ rutin equivalents/g dry weight plant extract (Table 2).

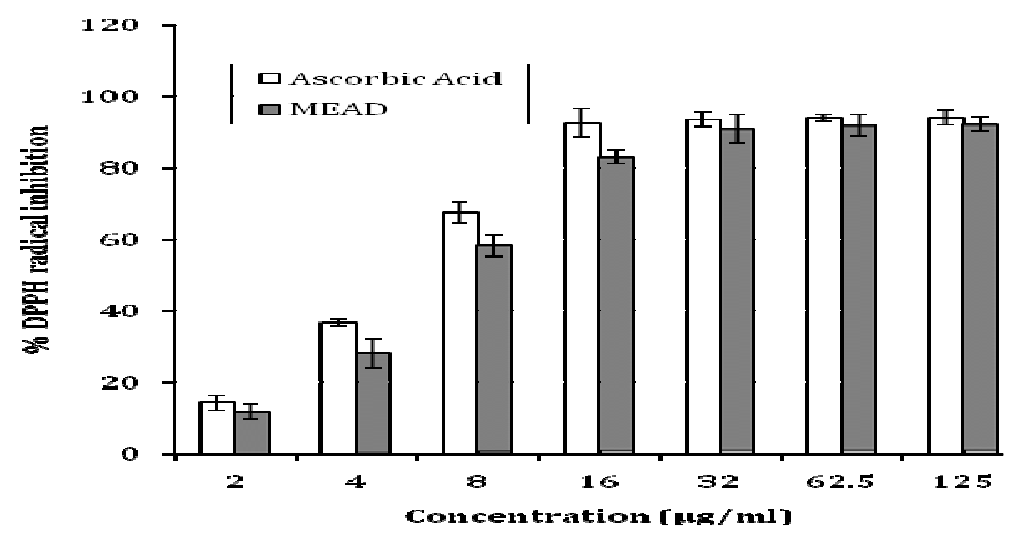

Figure 1: Inhibition of DPPH radical by methanol extract of A. djalonensis (MEAD) compared with the antioxidant activity of L-ascorbic acid. The results are expressed as mean \pm SEM $(n=3)$.

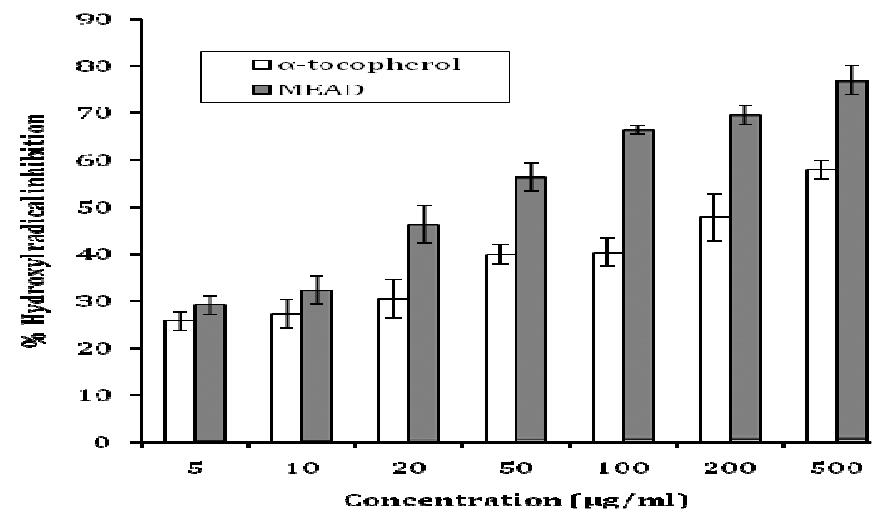

Figure 2: Inhibitory effect of methanol extract of A. djalonensis (MEAD) on hydroxyl radical mediated deoxyribose degradation compared to $\alpha$-tocopherol. The results are expressed as mean \pm SEM of three independent experiments. 


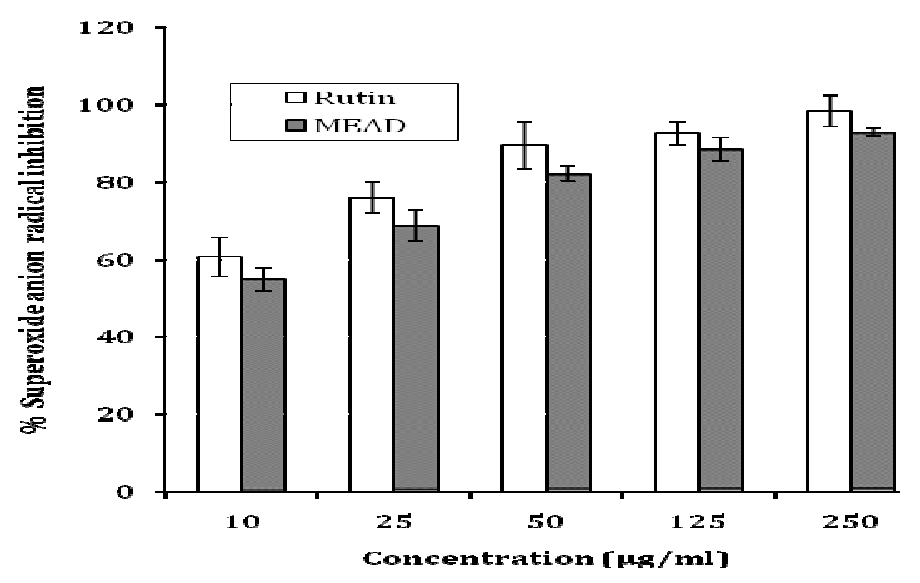

Figure 3: Scavenging effect of methanol extract of A. djalonensis (MEAD) on superoxide anion radical by inhibition of the photoreduction of NBT. The results are expressed as mean \pm SEM of three independent experiments.

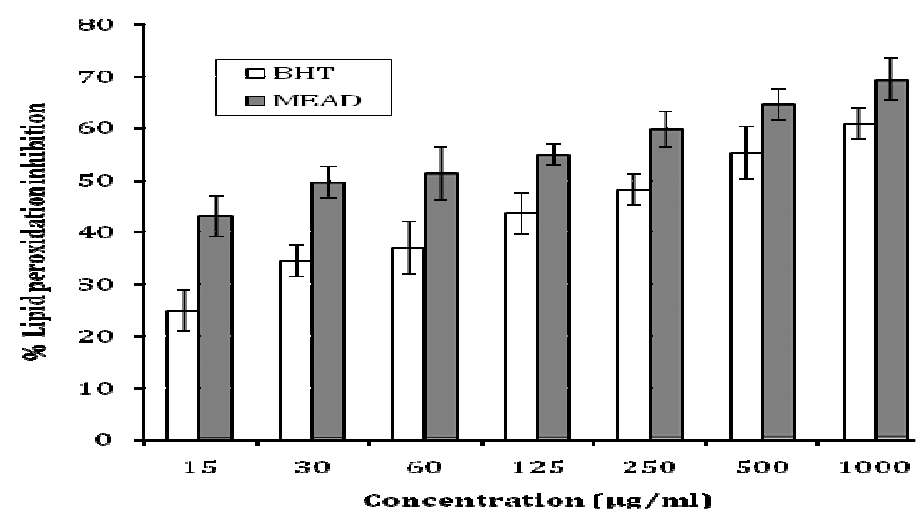

Figure 4: Inhibitory effect of methanol extract of A. djalonensis (MEAD) on lipid peroxidation induced by $\mathrm{Fe}^{2+} /$ ascorbate system. The results are expressed as mean $\pm \mathrm{SEM}$ of three independent experiments.

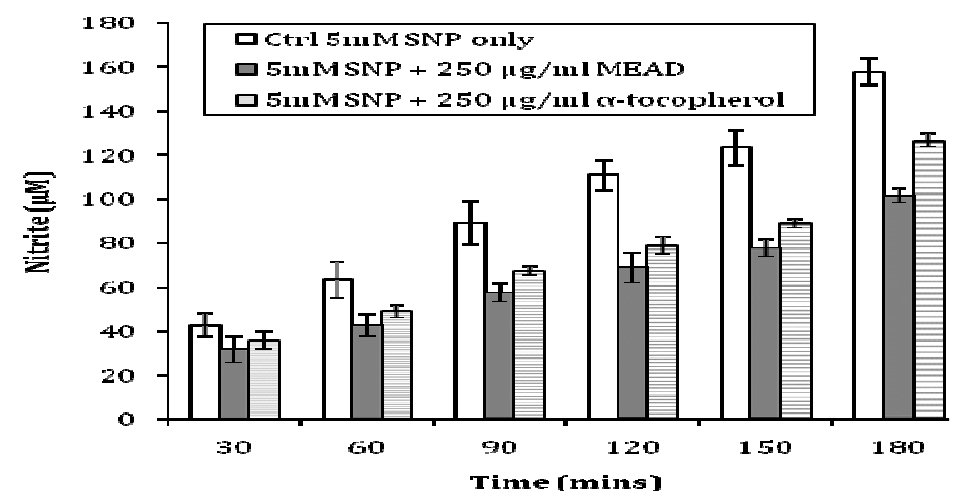

Figure 5: Effect of methanol extract of A. djalonensis (MEAD) leaves on the accumulation of nitrite upon decomposition of SNP; $(5 \mathrm{mM})$ at $25^{\circ} \mathrm{C}$. Each plot represents the mean $\pm \operatorname{SEM}(\mathrm{n}=3)$. 
Table 1: The $\mathrm{IC}_{50}$ values for the inhibition of free radicals by methanol extract of A. djalonensis (MEAD) compared to standard antioxidants.

\begin{tabular}{|c|c|c|c|c|}
\hline \multirow[t]{2}{*}{ Sample } & \multicolumn{4}{|c|}{$\mathrm{IC}_{50}(\mu \mathrm{g} / \mathrm{ml})^{*}$} \\
\hline & DPPH' radical & OH radical & $\mathrm{O}_{2}{ }^{-\sim}$ radical & Lipid peroxidation \\
\hline MEAD & $8.69 \pm 0.95^{\ddagger}$ & $33.06 \pm 5.65^{\ddagger}$ & $5.32 \pm 1.05^{\dagger}$ & $59.14 \pm 4.64^{\sharp}$ \\
\hline Ascorbic Acid & $4.35 \pm 0.51$ & - & - & - \\
\hline$\alpha$-tocopherol & - & $232.31 \pm 6.97$ & - & - \\
\hline Rutin & - & - & $3.47 \pm 0.65$ & - \\
\hline BHT & - & - & - & $216.27 \pm 7.92$ \\
\hline
\end{tabular}

Table 2: Total flavonols, flavonoids and phenol contents of methanol extract of A. djalonensis (MEAD)

\begin{tabular}{llllll}
\hline Plant extract & $\begin{array}{l}\text { Total } \\
\text { flavonols * }\end{array}$ & $\begin{array}{l}\text { Total } \\
\text { flavonoids * }\end{array}$ & \multicolumn{3}{c}{ Phenolic contents $\dagger$} \\
\cline { 3 - 5 } & & $\begin{array}{l}\text { Total } \\
\text { Phenols }\end{array}$ & Non-tannins & Tannins \\
\hline MEAD & $28.52 \pm 0.34$ & $48.52 \pm 1.10$ & $0.989 \pm 0.097$ & $0.508 \pm 0.059$ & $0.481 \pm 0.037$ \\
\hline $\begin{array}{l}\text { Data represented as Mean } \pm \text { SD }(\mathrm{n}=3) ; * \text { Expressed as mg rutin equivalents / g dry weight plant extract; } \uparrow \text { Expressed as mg } \\
\text { gallic acid equivalents } / \mathrm{mg} \text { dry weight plant extract. }\end{array}$ & & & &
\end{tabular}

\section{DISCUSSION}

Medicinal plants have become extremely popular all over the world as antioxidants and in recent past several dietary and herbal formulation, which have free radical scavenging potential have gained important in treating chronic diseases (Tiwari and Tripathi, 2007). In biological systems, reactive oxygen species (ROS) and reactive nitrogen species (RNS) are continuously generated and they plays a role in the pathogenesis of many disease conditions by causing extensive damage to biomolecules and tissues (Eze, 2006; Catala, 2009).

The extract showed a potent DPPH radical scavenging potential. The addition of the MEAD and standard to the DPPH solution caused a rapid decrease in absorbance at 518 $\mathrm{nm}$ indicating good scavenging capacities. The antioxidant compounds in the extract and the standard neutralized the free radical character of DPPH by transferring either electrons or hydrogen atoms to DPPH (Naik et al., 2003), thereby changing the color from purple to the yellow colored stable diamagnetic molecule diphenyl picrylhydra- zine. This interaction depends on the structural conformation of the bioactive compounds present in the plant extracts of which the hydroxyl groups of flavonoids are highly favorable (El-Sayed, 2009). The degree of discoloration indicated the scavenging potential of the extracts in term of hydrogen donating ability (Mosquera et al., 2007).

Hydroxyl radicals $(\mathrm{OH})$ are the major active oxygen species causing lipid peroxidation and enormous cellular and tissue damage (Catala, 2009). The effect of MEAD on $\mathrm{OH}$ radicals generated by $\mathrm{Fe}^{3+}$ ions was measured by determining the degree of deoxyribose degradation, an indicator of thiobarbituric acid-malonaldehyde (TBAMDA) adduct formation. This complex forms a pink chromogen upon heating with TBA at low pH (Ruberto et al., 2000). The antioxidant components in the plant extracts competed with deoxyribose against the $\mathrm{OH}$ radical generated from the $\mathrm{Fe}^{3+}$ dependent system and prevented the reaction. In this study, the extract was a more effective $\mathrm{OH}$ radical scavenger compared to the standard antioxidant $\alpha$-tocopherol. The antioxidant(s) 
in this plant extracts could be acting as chelators of the $\mathrm{Fe}^{3+}$ ions in the system thereby preventing them from complexing with the deoxyribose, or simply donating hydrogen atoms and accelerating the conversion of $\mathrm{H}_{2} \mathrm{O}_{2}$ to $\mathrm{H}_{2} \mathrm{O}$ (Wang et al., 2007). The observed ability of the extracts to scavenge or inhibit $\mathrm{OH}$ radical indicates that the extracts could significantly inhibit lipid peroxidation since $\mathrm{OH}$ radicals are highly implicated in peroxidation.

Superoxide anion $\left(\mathrm{O}_{2}{ }^{-}\right)$radical is also very harmful to cellular components (Muller et al., 2007). The plant extract was observed to be an efficient scavenger of superoxide anion radical. The $\mathrm{O}_{2}^{--}$radical scavenging activities of the plant extract and the reference compound were increased markedly with increasing concentrations. The scavenging potential will possibly depend on the number and locations of the hydroxyl groups in the phenolic compounds present in the extract (Khanduja et al., 2006). The radical scavenging activity is also consistent with the high level of phenolic compounds observed in the plant extract, since phenolic compounds such as flavonoids are known to possess high $\mathrm{O}_{2}{ }^{-}$anion scavenging abilities (Rajendran et al., 2004).

Lipid peroxidation involves the formation and propagation of lipid radicals, which eventually destroy membrane lipids (Catala, 2006). The lipid peroxidation inhibitory potential of the extract and standard were assessed by the amount of MDA produced in the reaction mixture. Lipids in egg yolk undergo rapid non-enzymatic peroxidation in the presence of ferrous sulfate. The inhibition of lipid peroxidation by the extract was concentration dependent. $A$. djalonensis extract was found to be a more efficient lipid peroxidation inhibitor compared to butylated hydroxytoluene (BHT). This corroborates the observed high $\mathrm{OH}$ radical scavenging activity of the extracts and suggests that the extracts may afford a cytoprotective effect. Considering the destructive effect of lipid peroxides in several disease conditions (Muller et al., 2007), the ability of the extract to inhibit peroxidation could constitute part of the basis for the ethnopharmacological claims for its use.

Despite the possible beneficial effects of $\mathrm{NO}$, its contribution to oxidative damage is increasingly becoming evident. Sustained levels of production of this radical are directly toxic to tissues and contribute to the vascular collapse associated with septic shock, whereas chronic expression of nitric oxide radical is associated with various carcinomas and inflammatory conditions including juvenile diabetes, multiple sclerosis, arthritis and ulcerative colitis (Altug et al., 2000; Zou et al., 2004; Hosseini et al., 2006). The toxicity of NO increases when it reacts with superoxide to form the peroxynitrite anion $\left(\mathrm{ONOO}^{-}\right)$, which is a potential strong oxidant that can decompose to produce $\mathrm{OH}$ and $\mathrm{NO}_{2}$ (Pacher et al., 2007). The present study shows that the MEAD has more potent nitric oxide scavenging activity than the standard $\alpha$ tocopherol. The NO generated from SNP reacts with oxygen to form nitrite. The extract may inhibit nitrite formation by directly competing with oxygen in the reaction with nitric oxide.

Due to the potent free radical scavenging activity of the MEAD, it was subjected to some phytochemical analysis. The phytochemical screening revealed the presence of phenolic compounds as major bioactive components. Phenolics and flavonoids both have good antioxidant potentials with considerable effect on human nutrition and health (Knekt et al., 2002). The antioxidant activity of plant phenolic compounds are attributed to their redox properties, which allow them to act as reducing agents, hydrogen donators, singlet oxygen quenchers and metal chelators (Lotito and Frei, 2006).

This study, therefore, shows that the methanol extract of Anthocleista djalonensis (MEAD) exhibited high antioxidant and free radical scavenging activities and inhibited lipid peroxidation in vitro. The antioxidant properties indicate that this plant extract is a significant source of natural antioxidant and 
its potential could, to a greater extent, be attributed to its phenolic contents. Since ROS are associated with the pathogenesis of inflammatory diseases, diabetes, STI, etc. (Spiteller, 2006), the free radical inhibitory effect of the extract may partially justify its ethnomedicinal use in treating different disease conditions. It is however, worthwhile to further investigate the in vivo potentials of this plant and also isolate the active components which could ultimately lead to their application in pharmaceutical formulations.

\section{ACKNOWLEDGEMENTS}

The authors acknowledge the Chancellor of Madonna University, Okija, Very Rev. Fr. Prof. E. M. P. Edeh for his generous support.

\section{REFERENCES}

Altug S, Demiryurek AT, Kane KA, Kanzik I. 2000. Evidence for the involvement of peroxynitrite in ischaemic preconditioning in rat isolated hearts. $\mathrm{Br}$. J. Pharmacol., 130: 125-131.

Atta-ur-Rahman, Choudhary MI. 2001. Bioactive natural products as potential source of new pharmacophores. A theory of memory. Pure Appl. Chem., 73: 555560.

Awah FM, Uzoegwu PN, Oyugi JO, Rutherford J, Ifeonu P, Yao X, Fowke KR, Eze MO. 2010. Free radical scavenging activity and immunomodulatory effect of Stachytarpheta angustifolia leaf extract. Food Chem., 119: 1409-1416.

Catala A. 2006. An overview of lipid peroxidation with emphasis in outer segments of photoreceptors and the chemiluminescence assay. Int. J. Biochem. Cell Biol., 38: 1482-1495.

Catala A. 2009. Lipid peroxidation of membrane phospholipids generates hydroxy-alkenals and oxidized phospholipids active in physiological and/or pathological conditions. Chem. Phys Lipids, 157(1): 1-11.
Chah KF, Eze CA, Emuelosi CE, Esimone CO. 2006. Antibacterial and wound healing properties of methanolic extracts of some Nigerian medicinal plants. $J$. Ethnopharmacol., 104(1): 164-167.

El-Sayed SA. 2009. Total phenolic contents and free radical scavenging activity of certain Egyptian Ficus species leaf samples. Food Chem., 114: 1271-1277.

Esimone CO, Nworu CS, Onuigbo EB, Omeje JU, Nsirim KL, Ogbu JC, Ngwu MI, Chah KF. 2009. Anti-mycobacterial activity of root and leaf extracts of Anthocleista djalonensis (Loganiaceae) and Diospyros mespiliformis (Ebenaceae). Int. J. Green Pharm., 3: 201-205.

Eze MO. 2006. The oxygen paradox and the place of oxygen in our understanding of life, aging, and death. Ultim Real Meaning (URAM): Stud. Med. Health, 29(1): 46-61.

Gyamfi MA, Yonamine M, Aniya Y. 1999. Free-radical scavenging action of medicinal herbs from Ghana: Thonningia sanguine on experimentally-induced liver injuries. Gen. Pharmacol., 32: 661-667.

Halliwell B, Gutteridge JMC, Aruoma OI. 1987. The deoxyribose method: simple "test-tube" assay for determination of rate constants for reactions of hydroxyl radicals. Anal. Biochem., 165: 215-219.

Halliwell B. 2001. Role of free radicals in neurodegenerative diseases: therapeutic implications for antioxidant treatment. Drugs Aging, 18: 685-716.

Hosseini A, Renström LK, Ehrén I, AguilarSantelises M, Sirsjö A, Wiklund NP. 2006. Enhanced formation of nitric oxide in bladder carcinoma in situ and in BCG treated bladder cancer. Nitric Oxide, 15(4): 337-343.

Lotito SB, Frei B. 2006. Consumption of flavonoid-rich foods and increased plasma antioxidant capacity in humans: cause, consequence, or epiphenomenon?. Free Radic. Biol. Med., 41(12): 1727-46.

Khanduja KL, Avti PK, Kumar S, Mettal N, Sohi KK, Pathak CM. 2006. Anti- 
apoptotic activity of caffeic acid, ellagic acid and ferulic acid in normal human peripheral blood mononuclear cells: A Bcl-2 independent mechanism. Biochim. Biophy. Acta, 1760: 283-289.

Knekt P, Kumpulainen J, Järvinen R, Rissanen H, Heliövaara M, Reunanen A, Hakulinen T, Aromaa A. 2002. Flavonoid intake and risk of chronic diseases. Am. J. Clin. Nutr., 76 (3): 560-8.

Kumaran A, Karunakaran J. 2006. In vitro antioxidant activities of methanol extracts of five Phyllanthus species from India. LWT-Food Sci. Technol., 40: 344-352.

Makkar HPS, Bluemmel M, Borowy NK, Becker K. 1993. Gravimetric determination of tannins and their correlations with chemical and protein precipitation methods. J. Sci. Food Agric., 61: 161-165.

Martinez AC, Marcelo EL, Marco AO, Moacyr M. 2001. Differential responses of superoxide dismutase in freezing resistant Solanum curtibolum and freezing sensitive Solanum tuberosum subjected to oxidative and water stress. Plant Sci., 160: 505-515.

Mosquera OM, Correa YM, Buitrago DC, Niö J. 2007. Antioxidant activity of twenty five plants from Colombian biodiversity. Memorias do Instituto Oswaldo Cruz, 102: 631-634.

Muller FL, Lustgarten MS, Jang Y, Richardson A, Van Remmen H. 2007. Trends in oxidative aging theories. Free Radic. Biol. Med., 43: 477-503

Naik GH, Priyadarsini KI, Satav JG, Banavalikar MM, Sohoni DP, Biyani MK, Mohan H. 2003. Comparative antioxidant activity of individual herbal components used in Ayurvedic medicine. Phytochem., 63: 97-104.

Nweze NE, Ngongeh LA. 2007. In vitro anthelmintic activity of Anthocleista djalonensis. Niger Vet. J., 28: 9-13

Okoli AS, Iroegbu CU. 2004. Evaluation of extracts of Anthocleista djalonensis, Nauclea latifolia and Uvaria afzalii for activity against bacterial isolates from cases of non-gonococcal urethritis. $J$. Ethnopharmacol., 92: 135-144.

Pacher P, Beckman JS, Liaudet L. 2007. Nitric oxide and peroxynitrite: in health and disease. Physiol. Rev., 87: 315-424.

Rajendran M, Manisankar P, Gandhidasan R, Murugesan R. 2004. Free radicals scavenging efficiency of a few naturally occurring flavonoids: a comparative study. J Agric Food Chem., 52(24): 73897394.

Ruberto G, Baratta MT, Deans SG, Dorman HJ. 2000. Antioxidant and antimicrobial activity of Foeniculum vulgare and Crithmum maritimum essential oils. Planta Medica, 66: 687-693.

Spiteller G. 2006. Peroxyl radicals: Inductors of neurodegenerative and other inflammatory diseases. Their origin and how they transform cholesterol, phospholipids, plasmalogens, polyunsaturated fatty acids, sugars, and proteins into deleterious products. Free Radic. Biol. Med., 41: 362-387.

Tiwari OP, Tripathi YB. 2007. Antioxidant properties of different fractions of Vitex negundo Linn. Food Chem., 100: 11701176.

Velioglu YS, Mazza G, Gao L, Oomah BD. 1998. Antioxidant activity and total phenolics in selected fruits, vegetables, and grain products. J. Agric. Food Chem., 46: 4113-4117.

Wang J, Yuan X, Jin Z, Tian Y, Song H. 2007. Free radical and reactive oxygen species scavenging activities of peanut skins extract. Food Chem., 104: 242-250.

Wong C, Li H, Cheng K, Chen F. 2006. A systematic survey of antioxidant activity of 30 Chinese medicinal plants using the ferric reducing antioxidant power assay. Food Chem., 97: 705-711.

Zou MH, Cohen R, Ullrich V. 2004. Peroxynitrite and vascular endothelial dysfunction in diabetes mellitus. Endothelium, 11: 89-97. 